\title{
Is It Time For An Exchange Traded Futures Contract Based On A Housing Price Index?
}

Stephen A. Kane ${ }^{1}$ (E-mail: skane@suffolk.edu), Suffolk University John D. McCoy (E-mail: jmccoy@suffolk.edu), Suffolk University

\begin{abstract}
There is not a good hedging instrument to absorb housing price risk. An exchange traded futures contract based on a hedonic or repeat sale housing price index would help homeowners, originators, home builders, and others hedge housing price risk, but it does not exist, yet. We discuss the need and why it may be time for its introduction.
\end{abstract}

\section{INTRODUCTION}

$\mathrm{t}$ is often more desirable to own than to rent. Homeowners may take better care of their property than renters do. Furthermore, the federal government provides subsidies to encourage homeownership. The mortgage interest on household's primary residence is Federal tax deductible while paying the same amount in rent as a tenant is neither deductible nor equity accumulating. There are home improvement tax subsidies, too. Fannie Mae and Freddie Mac's status as government sponsored enterprises gives them an implicit subsidy in the form of a lower cost of debt. Much of this subsidy is subsequently passed on to homeowners through cheaper financing. Mortgage originators know they can sell the conforming portions of their mortgages to Fannie Mae and Freddie Mac and this lowers the cost of capital on mortgage loans.

Nevertheless, a potential homebuyer may be weary of housing price risk in a housing market where prices have inflated far ahead of other investments and income levels. The fear produced by a housing bubble or any bubble for that matter is that buyers may be purchasing at the high end just before a crash. First time homebuyers may delay the purchase of their home, because they do not have a good way to hedge the price risk. Some will wait anxiously for the market to stabilize or the bubble to deflate. They may miss out on many of the subsidies and other benefits until the housing price bubble bursts or stabilizes. These potential homeowners may also incur additional moving costs if they do eventually purchase a home.

An exchange traded futures contract based on a housing price index would help homeowners, originators, home builders, and others hedge housing price risk, but it does not exist, yet. The purpose of this paper is to evaluate whether or not it is time to create an exchange traded futures contract. We discuss shortcomings in residential real estate markets that have stifled the creation of an exchange traded futures contract. We analyze how a futures exchange might design a contract to mitigate these difficulties.

\section{PRICING}

Houses are differentiated products. This heterogeneity makes them difficult to price, because one home is an imperfect substitute for another home. In the long run, real estate prices reflect supply and demand, however, in the short run, there many other variables that drive the price of homes. In contrast, grains are homogenous. This makes them fungible. Legally, someone can substitute an equal amount of the same kind of gain, because one farmer's grain is nearly identical to another farmer's. Residential homes are not fungible. There are numerous, sometimes even conflicting, criteria driving prices. While the quality of the dwelling is a driving force, its location may be even more

\footnotetext{
${ }^{1}$ The authors thank Haluk Akdogan, Zhenhua Chan, Jennifer Chin, Heaven Fearn, Jane Huang, Richard Kane, Gene Mueller, Mark Muzere, and Anthony Petropolus for comments and software support that improved this manuscript.
} 
important. Some homebuyers invest less in bricks and mortar than in the hope of continued appreciation of the community due to schools, location to transportation, and perceived reputation.

Buyers, sellers and appraisers all base pricing upon recent sales of comparable properties. They consider: location; the age, condition, and construction quality of the property; the square footage; the number of bedrooms and bathrooms; various other amenities and other available properties. Interest rates and borrowing options influence buyers because this affects how much real estate they can afford. What occurs is a pricing dynamic for residential properties that has disparity based upon many interlocking and fluctuating economic and social dynamics. Attempting to estimate a housing price index based upon observables is difficult. There are two major techniques: repeat sale and hedonic indices. Without adjusting for home improvements, repeat sale index consider the price appreciation of homes that have sold twice during the relevant time period. A hedonic price index uses multivariate regression to adjust home prices for specified variables that an investigator postulates affects home prices. We discuss contractual concerns with both techniques later in the paper.

\section{THE NEED}

First-time homebuyer without many other assets did not face the full downside of the price risk in their homes. If their home price dropped substantially after living in their home for a while, they could turn in the keys to originating financial institution. Since these borrowers lacked sufficient assets use to repay their debt, it was not worth the financial institution's trouble to pursue them into bankruptcy. The 2005 revision of the federal bankruptcy code has changed this, however, because lenders can now place a twenty-year lien against borrowers. Instead of discharging an obligation, a lender can hope that such borrowers will eventually have resources to repay them. In turn, this may affect the foreclosure rate as more homeowners find themselves financially overextended.

Some lenders are granting homebuyers mortgages far in excess of three times their annual income. As more and more prospective homeowners leap into the red-hot housing market they do so with the use of variable rate loans, flexible payment loans, and interest only loans. The gap between household income growth and housing prices has become a canyon like in the late 1990's and early part of the $21^{\text {st }}$ century. Non-traditional mortgages provide attractive vehicles for homebuyers priced out of hot housing markets, desirable locals, and spacious structures. The holders of the mortgage pass-through securities hold some home price risk. The pass-through securities may be regionally diversified by how Fannie and Freddie pool their mortgages, but this does not hedge holder against rising interest rates. An originating institution may hold some of the price risk, too. Many will have sold their mortgage contracts to Fannie Mae or Freddie Mac. In this case, they may have some residual risk resulting from the performance contracts that Fannie and Freddie impose on mortgage originators.

\section{FUTURES}

For a specified commodity, a forward contract is an agreement that specifies delivery of the underlying commodity at a predetermined date with a currently agreed upon price. A financial forward contract is an agreement that specifies a financial instrument such as an index at a given future date at a currently agreed upon price. With a financial instrument, however, there is no delivery of the underlying. Instead, an offsetting cash payment is made between counterparties. A futures contact is often an exchange traded forward contract. The exchange serves as the counterparty. Hence the exchange assumes the credit and other nonperformance risk. To mitigate this risk, exchanges require transacting parties to post margin accounts. The required amount of margin depends on the volatility of the underlying futures contracts. Exchanges mark these accounts to closing market prices on a daily basis. If a transacting party is unable to maintain the margin account, then exchanges close out the position by offset.

\section{THE CONTRACT}

The Federal government through the Office of Federal Housing Enterprise (OFHEO) publishes a national repeat sale-housing index based on the mortgages that are sold to Fannie Mae and Freddie Mac. OFHEO specify the formulas that they use to compute their indices. Market participants may be willing to accept these government indices as impartial just as they have accepted the Bureau of Labor Statistics Consumer Price Index-Urban basket, a 
measure of inflation. For example, the Chicago Mercantile Exchange uses the CPI-U as an index for futures contracting. Unfortunately, a home price index may have more severe downward revisions than a CPI-U index, because there is bias in the sample since homes that sell more frequently tend to have better price appreciation. ${ }^{2}$ Flipped homes (resold within two years) and starter homes tend to receive more improvements before resale. They enter repeat sale indices sooner than other homes that people own for decades, because starter home transact more frequently. When these other homes finally resell they tend to introduce a downward revision to indices, since they tend to receive fewer improvements.

This bias can be reduced somewhat by employing a hedonic price index (Clapham, Englund, Quigley and Redfearn, 2005). Hedonic indices may adjust for improvements made to homes, for instances, remodeled kitchen, remodeled bathrooms, and room additions. Nevertheless, the choice of a hedonic index may require contracting parties to specify all the details necessary to compute the index in advance, so that contracts can be settled by financial offset (Shiller 1993). These details include: the location of the homes for the sample, the time interval, the dependent variables, and how the estimation procedure will handle dependent variables that have a high linear correlation to decrease estimated parameter sensitivity. Additionally, some dependent variables used to adjust prices may require home inspections. Unfortunately, home inspections are not fully standardized nationally and this may restrict the choice of dependent variables, too.

We discuss two fledgling products (Hagerty 2005). (1) "The PHLX Housing Sector ${ }^{\mathrm{SM}}\left(\mathrm{HGX}^{\mathrm{SM}}\right)$ is a modified capitalization-weighted index composed of 21 companies whose primary lines of business are directly associated with the U.S. housing construction market." ${ }^{3}$ This index may be positively correlated with housing prices, because housing construction companies should perform well when home prices are higher, but the linear correlation may only be a small positive number. Consequently, a hedging homeowner may not know how many shares of this index to sell short to hedge their home price risk exposure. (2) "HedgeStreet Inc. today announced that its market participants may now hedge or speculate on the direction of home values in major U.S. real estate markets, as well as the domestic supply of crude oil and natural gas." ${ }^{4}$ HedgeStreet offers customers to hedge housing price risk based on the median home sales in six metropolitan markets: San Francisco, Los Angeles, San Diego, New York, Miami, and Chicago. A homeowner in Boston or Washington DC, for instance, will not be able to hedge home price movements that are particular to their cities. Furthermore, a median home price for a metropolitan area will be affected by the quality of the homes for sale in the specified time period. Thus, factors that affect the quality of the homes that are transacting and not the value of the homes in the metropolitan area per se will also influence the median price.

\section{MANIPULABILITY}

How easy is it to manipulate a repeat sale housing price index? By changing the timing of a home closing, a sale could fall out of specified time interval. Which sales are eligible and which ones are not eligible? In the case of the OFHEO index, it is any home that has a conforming portion sold to Fannie Mae or Freddie Mac. For a mortgage refinancing the appraised value of the home is used as the sale price in the index. Many lenders elect to season some newly originated mortgages before they sell them to Fannie and Freddie. This means many transactions do not enter OFHEO database immediately when the sale of the home takes place.

Not only is there heterogeneity in homes sold and resold, there is a lack of consistency in the transactional process as well. States define real estate laws. This local aspect creates a lack of uniformity in how real estate contracts are defined, negotiated, enforced, and remedied for non-performance. Once a contract has been entered into, the parties set a tentative closing date. The closing date is the day when the actual transfer of the property is supposed to occur. Logistical issues such as moving, relocating, or the sale of the buyers home all affect the time for closing. Some homebuyers may already time closings to gain the largest cushion from taxes and mortgage payments. Buyers and sellers may affect the market timing without directly attempting to do so, based upon the time frame chosen for

\footnotetext{
2 The CPI-U experiences a major revision when the base year and corresponding market basket that a representative urban consumer purchases changes. For instance, there are many good and services that are available in 2005 that were not available in 1984.

${ }^{3}$ http://www.phlx.com/products/hgx.html

${ }^{4} \mathrm{http}: / / \mathrm{www}$. hedgestreet.com/abouthedgestreeet/pressreleases/pressrelease_13.html
} 
closing. A contract for the sale of a home negotiated and entered into in the summer months may nevertheless close the following year. To further complicate matters; scheduling, property title and financing issues may alter closing dates, too.

How to define the location for the index? A single metropolitan area as defined by Census Bureau in the Commerce Department might not be large enough to use for an exchange-traded index due to manipulability concerns. Consequently, an exchange might want to trade a national index, and an index based on major, say 5 million plus metropolitan area population.

\section{MARKETING ISSUES}

There may be interest in the contract, but there may not be sufficient volume from speculators to make the introduction of the contract worth the exchanges trouble. Indeed, an exchange traded futures contract may not be ready for prime time. Such contracts may have to work elsewhere before an exchange will take them over. There have been past failures. For instance, Solomon Brothers tried a Commercial Real Estate Index in London in the mid 1980s.

Who might hold the risk before it is ready the contract is ready to be traded on an exchange? It is possible that hedge funds (through total return swaps) might want to hold this risk. To understand this, we need to think about the existing incentives for a hedge fund. They receive $20 \%$ of the upside returns in a given year as compensation for their services. Consequently, they seek high risk / high return investments. Further, they want more assets under management, because this will increase their returns, too. In order to increase assets under management, hedge funds need to perform better than their peers. This means that they will be attracted to investments that in the short run promise high returns even though they have high risk in the long run. In the short term, hedge funds will get the higher returns (and possibly more assets under management) while accepting the long run risk.

What areas are most exposed to price risk? There is more downside potential in poor neighborhoods, all else equal. In the past, poorer neighborhoods experienced most of the foreclosures. For instance, there tends to be more unemployment in poorer neighborhoods. This might induce some homeowners to sell their homes when they relocate to a different city for employment purposes. The homes will compete with foreclosure sales of similar homes. As a consequence, a home in a poorer neighborhood may be less liquid than one in a wealthier neighborhood in an economic downturn.

\section{SUBSTITUTE FOR PMI?}

Is it possible for price-level insurance contacts to replace or augment private mortgage insurance? At least a price-level insurance contract would help reduce the risk in private mortgage insurance, but it might be possible to have it replace it, too. How to design the mortgage contract? For instance, will homeowners accept a larger principal if the value of their home appreciates in return for a lower principal when the value of their home depreciates?

\section{BUBBLE}

We discuss three symptoms of a housing price bubble: Income gap, a drop in monthly rental prices caused by new construction, and home prices outstripping replacement costs. The old rule of thumb is three times a household's annual income for mortgage on a house. We see many lenders granting homebuyers mortgages far in excess of three times their annual income. When mortgages are four or five times the annual household income, there is the possibility for a housing bubble burst, because the incomes in the area do not support the housing prices. Renting is an imperfect substitute for homeownership. For example, a drop in the monthly rental prices spurred by new construction (dorms in Boston, for instance) and this may foreshadow a drop in home prices. Housing prices outstripping new construction (replacement cost). In the long run, if housing prices (demand) go up faster than replacement costs, then new constructions will increase the supply of new homes and will eventually bid down the prices. Furthermore, business may choose to locate or relocate in cheaper metropolitan areas if price wedges become severe. 
Demographics, in particular the baby boom generation's need for housing, has cause a greater demand for housing. New construction has not kept pace with demand. The value of land near urban centers has also appreciated due to the recent run up of gasoline prices. This makes commuting more expensive, all else being equal, and raises the value of homes closer to city centers. Additionally, the gasoline tax used to finance highway construction has stayed constant at thirteen cents per gallon and not kept pace with inflation. Thus, many outlying areas where new construction might take place still lack the same level of highway access that older communities enjoy. Consequently, we do not see the downward price pressure on older homes exerted by newly constructed homes that we observed in the recent past.

The drop in interest rates has spurred the bubble, too. Many households buy as much housing as they can afford. If interest rates a low, then a household may finance a larger principal, because the monthly payments will be lower. Furthermore, falling interest rates have reduced the discounting rates investors use to evaluate cash flows. This increases the present value of the cash flows, all else equal. Consequently, the value of the home to the owner (as if the household rented from themselves) has gone up, all else being equal.

Why has the value of the land appreciated so much? New York, Boston, and San Francisco are all land constrained. Much of the nearby land has already been developed. In the case of New York, Boston, and San Francisco they are constrained by major bays, harbors, and some wet lands. By preserving the historical character and architecture of existing neighborhoods, many cities have made zoning high-rise apartments difficult. Further, geographical restrictions such as the ability to get footings into bedrock, for instances, Gramercy Park in New York City, and the Fen way and Back Bay in Boston, may limit the height of buildings, too. This means that the value of the land on which the housing sits has appreciated much in value. Although many homes have seen substantial improvements (new kitchens and bathrooms, room additions, etc.), it is not sufficient to explain the huge price run up. Nationally, we might proxy for home improvements by looking at the difference between a repeat sale indexes (published by OFHEO) over a hedonic price indexes (that adjust for home improvement), roughly 8\%-5\% (Holt, 2003). ${ }^{5}$ New construction costs (replacement costs) have been growing at a rate between two and three percent per year. Instead, it is the value of the land on which the dwelling sits that has appreciated roughly two to three percent per year with a recent large up tick. Due to a scarcity of new construction (substitutes for existing homes), the up tick has been higher for homes located in land constrained urban areas.

\section{CONCLUSION}

Homeowners may find themselves financially overextended. With the changes to the Federal bankruptcy code that took effect in late 2005, such homeowners will find it difficult to use Federal bankruptcy protection to have their debt discharged. Consequently, many homeowners may want to layoff the price risk. Unfortunately, suitable hedging instrument do not exist, yet. Consequently, it may be time for the introduction for an exchange trade futures contract based on a housing price index.

\section{REFERENCES}

1. Bankruptcy Abuse Prevention and Consumer Protection Act of 2005, S.256, A bill to amend title 11 of the United States Code, and for other purposes. Public Law No: 109-8, 2005.

2. Holt, Derek, 2003. What's a house worth? Current Analysis.

3. Shiller, Robert J. (1993) Measuring Asset Values for Cash Settlement in Derivative Markets: Hedonic and Repeat Sale Measures Indices and Perpetual Futures, Journal of Finance, 48:3, 911-931.

4. The Chicago Mercantile Exchange CPI-U futures index: www.cftc.gov/foia/fedreg97/foi970814a.htm www.futuresmag.com/press releases/ex100203b.html

5. Eric Clapham, Peter Englund, John Quigley, and Christian Redfearn (2005), Revisiting the Past and Settling the Score: Index Revision for House Price Derivatives, Working Paper, Berkeley Program on Housing and Urban Policy.

6. Hagerty, James R., New Tools to Hedge Your Home, Exotic Investments Products Target Anxious Owners Eager to Lock In Their Gains, The Wall Street Journal, Saturday/Sunday September 17 - 18, 2005.

\footnotetext{
${ }^{5}$ Repeat sale and hedonic indices are not directly comparable. For instance, estimators of indices may have used a different sample and time interval for estimation. At best, a difference between indices is a crude approximation.
} 